\title{
Analysis of Public Policy in Creating Public Information Service Image in Secretariat General of the House of People's Representatives of The Republic of Indonesia
}

\author{
Eko Sugiyanto \\ Post Graduate Program, Universitas Nasional \\ Jakarta, Indonesia \\ eko.unnas@gmail.com
}

\begin{abstract}
Public policy is a set of instructions made by the decision-makers for the executive that seek both objectives and methods to achieve the objectives. Public policy is influenced by several environments, namely, the manufacturing environment, the implementation environment, and evaluation environment. This study aims to investigate the implementation of public information service within the environment of the Secretariat General of the House of People's Representatives of the Republic of Indonesia (DPR RI), as well as to determine whether the public information service within the environment of the Secretariat General of the House of People's Representatives of the Republic of Indonesia (DPR RI) has been optimal as expected by the society. The approach in this study uses the normative approach; an approach taken to analyze the extent to which a regulation is in force and implemented effectively. In this case, the approach used is to analyze a wide range of operations of the public information services in accordance with the policies issued by the House of People's Representatives (DPR) which then applied on the Secretariat General of the House of People's Representatives of the Republic of Indonesia (DPR RI) in accordance with the policy. The study result reveals that transparency in public information services provides a significant impact to the society as service users. Based on the study result, it is indicated that the Bureau of Public Relations of the Secretariat General of the House of People's Representatives of the Republic of Indonesia (DPR RI) has been able to apply the principles of transparency on public information. This means that the information released by the Bureau of Public Relations of the Secretariat General of the House of People's Representatives has met the rights on public information.
\end{abstract}

Keywords: House of People's Representatives; Public Information Service Image; Public Policy; Indonesia.

\section{Introduction}

Dealing with the globalization era that is full of challenges and opportunities, the state apparatus are required to be able to provide the finest services oriented to the needs and the satisfaction of the service users, so as to increase competitiveness in the provision of either goods or services [1]. Act No. 32 of 2004 contains a spirit for the creation of improved services to the public. Delegation of authority from the central government to local governments allows the provision of services by the bureaucracy that is more compact, and also provides opportunities for local governments in the provision and improvement of the service quality. Public service is the provision of services (serving) for the person or people who have an interest in the organization in accordance with the basic rules and procedures that have been established [2]. In the Great Dictionary of Indonesian Language (KBBI), it is described that service is as an attempt to serve the needs of others, while serving is to help to set up (take care) what a person needs. In the 
general public services in Indonesia, the state apparatus act as a servant of the state and a public servant in which there are dominant groups both in terms of the role of the services as well as in terms of the number of services provided by the government to meet the public interest [3]. One of the embodiments of the functions of the state apparatus is the public service. The development of public services is one of the strategic choices to develop good governance in Indonesia. This is because one of the benchmarks of the implementation of good governance can be seen from the implementation of public services that has good quality and satisfaction oriented.

The state apparatuses have a decisive role on the successful implementation of the general tasks of the government and on the establishment of the tasks of services to the society. This can be achieved by realizing the objectives and the targets of the state apparatuses that function to serve professionally, effectively, productively, transparently, as well as free from corruption, collusion and nepotism, also being able to perform and implement the good governance. The application of the principles of good governance in the management of government that becomes a key demand on the intensification of the service performance by the state apparatuses is considered to be increasingly more important, because excellent service would have an impact on the achievement of a benefical business climate [4-6]. The principle tasks and functions of the state apparatuses gradually become the public spotlight for receiving good service is the right of the people, whereas the apparatuses are obliged to carry out the service thoroughly with the principles of service that is simple, quick, precise, steady, low-cost, transparent and nondiscriminatory. The society does not only require more efficient and satisfying public services, but they also expect more responsive action of the public administration that reflects fairness and balance of ethics and good judgment. The vigorous demands made by the people to the government are reasonable demands that should be responded by the government by making attentive changes by the increasing realization of the implementation of good governance [7].

In the development of the life of human beings, information is always occupied an important position, both as a means of enhancing knowledge and also practically as a commodity to maintain the existence of life. In other words, humans could not live without information. There is even an adage or ethos saying "who controls the information, he/she is the king, and who controls the information process, then he/she is the ruler". Rights on information was arising from the basic idea that human nature has a curious nature (curiosity), but the need of information of every community is not always the same. The increasing demand for information is caused by the accumulation of social life and human interaction with their environment. There are three basic concepts underlying the complete necessity of the information, namely (1) the development of human beings individually (2) the development of the environment where the individual is, and (3) the development of society. The era of open-door information born along with the agenda of democratization in Indonesia has spawned a variety of regulations on the access of public information. One of them that is considered to be the initial momentum of the the disclosure of information in Indonesia is Act No. 14 of 2008 on Public Information Disclosure. In concept, the right to get information can be understood as a manifestation of full accountability of the country to the people. Public organizations, financed by the people and supervised by elected public officials, have a responsibility to carry out their tasks openly. Transparency is one of the central differences between democratic government and the authoritarian regime. Accountability is the foundation of democracy, and the right to get the information provides such accountability mechanisms.

Practically, information is an important tool for the public officials to conduct supervision. The right to obtain information is also the basis of social and personal development. In a democratic society, the right to obtain information is certainly fundamental in upholding sovereignty, because it provides an opportunity for every citizen to monitor their officials and encourage popular participation in governance, to 
advance the goal of governance that is transparent, effective, efficient and accountable. The right on obtaining information essentially contains three main elements, including (1) the right to collect information, (2) the right to disseminate information, and (3) the right to communicate information. Those three elements are a unity that cannot be partially selected and separated. However, it is undeniable that the information is attached to the the condition of the public education and is often used as a commodity. Therefore, not every information can be disseminated to the public. Dissemination of information without the selection may cause interference or instability of public life.

Therefore, it should be understood that the process of collecting and processing information, on one side contains private domain, and on the other side, there is the authority of the state in the government domain which then is categorized as public domain. Restrictions on the flow of information carried out by authorized institutions should follow the outlines and procedures that have been agreed in accordance with the mechanism of applicable law [8]. The restrictions are intended to be an attempt to prevent bias from the information that can damage the pillars of peaceful coexistence. The Act regulates the meaning of public information; public information is information that is generated, stored, managed, delivered and/or received by a Public Body with regard to the state administrators and state administration and/or the other public body administrators and administration in accordance with this Act as well as other information related to the public interest".

The Act requires that public board to issue regulation on Public Information Disclosure. In this context, the House of People's Representatives of the Republic of Indonesia (DPR RI) as a public body has issued Regulation No. 1 of 2010 on Public Information Disclosure in DPR RI, stating that Public Information in DPR RI is the information generated, stored, managed, delivered, and/or accepted by the DPR through the Secretariat General of DPR RI and those related to the administrators and the administration of tasks and functions of the DPR and the Secretariat General of DPR. In addition, in order to promote the establishment of transparent and good governance as a reflection of democracy in Indonesia, DPR fully supports the contribution and participation of people in every public policy making. Therefore, it is normal when transparency and accountability become the core values embodied by the DPR RI by opening the access widely to information for the public in accordance with appropriate laws and regulations in force.

Functionally, the legislative institution must change the foundation to grant the rights to receive information concerning the performance of the public officials. In Indonesia, these officials are used to keep the information they have confidential, except the limited documents intended for public consumption. By the existence of the rights to obtain information, all information held by public authorities is now the main subject for a disclosure, unless, the confidentiality can be justified if the reason is that information may harm the interests protected by law, and the risk may exceed the public interest to obtain transparency. However, whether the implementation of freedom of public information is already well operated in DPR RI as that has been in commissioned by the Act No. 14 of 2008 on Public Information Disclosure and in accordance with the Regulation of DPR RI No. 1 of 2010 on Public Information Disclosure in DPR RI. In its practice, the regulation on the public information disclosure in Indonesia has not well implemented since the issue of the Act of Public Information Disclosure. The implementation of the Act of Public Information Disclosure by the governmental boards are poor and unjust, though the Commission of Information has made the regulation on the standards of public information services. This is partly due to the lack of public awareness concerning the importance of access to public information. The implementation of a regulation can run well or even worse. Righteousness and wickedness can certainly affect the image of an entity, in this case, the House of People's Representatives of the Republic of Indonesia (DPR RI). 
By the current precarious politics, it can be seen that the image of the House of Representatives has deteriorated, but this fact is not in regard with the fact of hard work of the members of the Board. Therefore, the image of DPR RI is always questionable.

Therefore, this paper present an analysis of public policy in creating public information service image in secretariat general of the house of people's representatives of the Republic of Indonesia. It is aimed to investigate the implementation of public information service within the environment of the Secretariat General of the House of People's Representatives of the Republic of Indonesia (DPR RI). Furthermore, it determines whether the public information service within the environment of the Secretariat General of the House of People's Representatives of the Republic of Indonesia (DPR RI) has been optimal as expected by the society.

The rest of this paper is organized as follow: Section 2 describes the proposed method. Section 3 presents public policy in the realization of the image of public information service in the general secretariat of DPR RI. Section 4 concludes this work.

\section{Proposed Method}

The method used in this study is descriptive, in order to make the annotations systematically, factually, and accurately regarding the facts and the properties of the population or a particular location. The research analysis is only to the extent of the description stage, which analyzes and presents the facts systematically, so that it can be easier to understand and conclude. Descriptive research studies the problems in society, as well as the applicable procedure in the community as well as the situation of certain circumstances, including the relationships, activities, attitudes, views, and the processes taking place and the influences of a phenomenon [9]. Moreover, the approach used is the normative approach.

\subsection{The Concept of Public Policy}

The meanings and substances of the public policy directly or indirectly have been widely known in the society along with a wide range of phenomena and activities occured in the government. There are many opinions conveyed by some experts with diverse definitions. Public policy, according to Dye [10], is defined as "Whatever governments chooses to do or not to do". Public policy is what the government choose to do or not to do. This meaning indicates that the government has the authority to make the choice of which policies that should be taken, depending on the problems arising or the objectives of the policies made. Meanwhile, the understanding of the policy, proposed by Nugroho in [11] is "A relative stable, purposive course of action followed by an actor or set of actors in dealing with a problem or matter of concern". Policy is a course of action that has an intention assigned by an actor or a set of actors in overcoming a problem or issue.

The meaning of public policy nowadays is enormously diverse; however, the notion of public policy is in the field of what to be done and not to be done by the government as policy maker. To make it easier to understand the meaning of public policy, we elaborate some of the opinions of experts including: Bridgman and Davis in [12], Hogwood and Gunn in [13]. According to [12], public policy is no more than the understanding of "Whatever government choose to do or not to do". According [13], public policy is a set of actions taken by the government designed to achieve certain objectives. In my opinion, public policy is an instrument made by the government in the form of general or specific rules, both written and unwritten that contain the options of actions including necessities, restrictions and or skills applied to regulate all citizens, government and business with specific purposes. Dunn in [14] defines the term public policy in his book entitled Public Policy Analysis, as follows: 
"Public policy is a complex pattern of dependence of interdependent collective choices, including decision not to take an action, made by the bodies or governmental officials".

Public policy, as proposed by Dunn, indicates the collective choices depending on each other, including the decisions to take an action. Public policy is made by the governmental agency or office. When a policy is made, then it needs to be implemented by the administrative units that mobilize financial and human resources. Tangkilisan [15], in his book Kebijakan Publik yang Membumi (Grounded Public Policy), who conveys that public policy is whatever governments choose to do or not to do. Based on the notion conveyed by Dye [10], public policy is whatever governments choose to do or not to do regarding to an action. The similiar idea with Dyes's in [10] is the opinion of Edward [16] and Widodo [17] saying that public policy is:

\section{"What government say and do, or not to do. It is the goals or purpose of government programs"}

The idea of Edward [16] and Widodo [17] also suggests the existence of what to be done or not to be done. This is related to the goals and targets contained in the programs that have been created by the government. Wahab in his book entitled Analisis Kebijakan: Dari Formulasi ke Implementasi Kebijaksanaan Negara (Policy Analysis: From Formulation to Implementation of State Policy) [18], who interprets the policy as:

"Policy is an action that leads to the goals proposed by a person, group or government in a particular environment in accordance with certain constraints while seeking opportunities to achieve goals or realize the desired goals"

According to Harold [34], policy is defined as intellectual tasks of making decisions which include a variety of items: a description of desired objectives to achieve, the description of the tendency to choose a number of purposes in accordance with the circumstances, the development of the impact and the performance of the policy in the future, as well as to make the script and conduct evaluation. Widodo defines public policy as a series of actions that have a specific purpose followed and implemented by the actor or a group of actors in order to solve specific problems [17].

Policy contains an element of action to achieve the goals. Generally, these goals are intended to be achieved by a person, group or government. A policy certainly contains obstacles, but it must seek the opportunities to achieve the desired objectives. Nakamura and Smallwood in [19] convey that the meaning of public policy is "a set of instruction from policy makers to policy implementers that spell out both goals ang the mean for achieving those goals".

Based on the understanding above, the public policy is a set of instructions generated from the decision-makers to the implementers of policy that attempt to make the goals and methods to achieve such goals. The public policy is influenced by several environments, namely; the manufacturing environment, the implementation environment, and evaluation environment. Kartasasmita in [33] also defines policy as an attempt to understand and indicate:

a. what to do (or not to do) by the government regarding to a problem;

b. what things causing and inlfuencing the policy;

c. what are the effects and impacts of the policy [17].

Policy is not just about what to be done or not to be done by the government, but also what things that cause or influence them, till a policy arises. Policy is generated to solve problems or issues in the society, so that eventually, the influence and impact of the policy can be noticed. Budiardjo in [20] states that policy is a collection of decisions 
taken by an actor or a political group in an attempt to choose the objectives and methods to achieve them.

Based on the definition above, it can be identified that policy is a compilation of decisions. The decisions are taken by an actor or by a political group, in this case, the government, trying to decide the goals and how to achieve them. Dahlan Thaib and Jazim Hamidi in their book Teori dan Hukum Konstitusi (Theory and Constitutional Law), argue that policy is any action or behavior of someone or rulers in the state administration. Based on the understanding above, elements contained in public policy could be found, as well as what is raised by Anderson in Widodo's book entitled Good Governance telaah dari Dimensi: Akuntabilitas dan Kontrol Birokrasi pada Era Desentralisasi dan Otonomi Daerah (Good Governance Studied from the Dimension: Accountability and Control of Bureaucracy in the Era of Decentralization and Regional Autonomy) [21]. Such elements include:

a. Policy always has a purpose, or should be goal-oriented;

b. Policy provides actions or an array of actions of the governmental officials;

c. Policy is what should be actually done by the government, and not what they intend to do;

d. Public policy has a positive trait (the government's action regarding specific problem) and a negative trait (governmental officials' decision not to do something);

e. Public policy (positive), is always based on specific authoritative legislation [17].

According to the elements contained in the policy as mentioned above, it can concluded that public policy is made within the framework to solve problems and to achieve certain desired goals and targets. Public policy is concerned with what is actually carried out by the government and not just what they want to do.

Policy, according to Anderson in Islamy [22], is:

"A purposive course of action followed by an actor or set of actors in dealing with a problem or a matter of concern".

However, Frederich in Wahab [18] limit the public policy by describing that policy is:

"An action that leads to the goals proposed by a person, group or government in a particular environment with respect to certain constraints while seeking opportunities to achieve goals or realize them".

The other experts also convey their opinins, like [16,22]:

"The state policy is an action taken or not taken by the government". The policy of the state may be in the form of legislation used to achieve goals, objectives of the programs and actions undertaken by the government".

In addition, according to Islamy [22]:

"The state policy is a set of actions defined and implemented or not implemented by the government that have purposes or have been goal-oriented for the sake of the entire society".

The policy taken turns to be meaningless without the element of repression to the implementers or the users of the policy to follow. This is in line with the opinion of Easton that defines policy as "the authoritative allocation of values for the whole society" [22], which implies that the policy contains the value of force that can be legitimately done by the government as the policy maker for the public. Referring to the opinion of experts $[16,17,22]$, it can be concluded that: 
"Public policy is a set of actions that have specific purposes oriented to the public interest (society). It aims to address the problem, and meet the desires and demands of all members of society. Policy also includes all actions of the government, done or not done by the government. The success of a policy depends on the support of the factors that influence the process of the policy."

Public policy, according to Dye in [10], is whatever governments choose to do or not to do. The concept is very broad because public policy includes something that is not done by the government, in addition to those implemented by the government when the government is dealing with a public issue. Meanwhile, according to Udaji in Wahab [18], public policy or policy of the state "An sanctioned course of action addressed to particular problem or group of related problems that affect society at large".

FurthermoreLasswell and Kaplan in Islamy [22] argue that public policy is a kind of "a projected program of goals, values and practices". Raksasataya in Islamy [22] also argues that "public policy is tactics and strategy addressed to achieve a goal." Therefore, a policy includes three elements:

a. Identification of desired goals;

b. Tactics or strategy of diverse steps to achieve the desired goals;

c. Provision of various inputs to enable real implementation of tactics or strategy.

Other definitions proposed by James Anderson is that "Public policy are those policies devoleped by governmental bodies and officials" [22]. The implications of the definitions conveyed by the experts above are:

a. Public policy always has a specific purpose or should be a goal-oriented action;

b. Policy contains actions or an array of actions taken by government;

c. Policy is what actually done by the government;

d. Public policy can be positive, in the sense that, it is a kind of the government's action on a specific problem; or it can be negative, in the sense that government's decision is not to do something;

e. The government's policy is always based on the authoritative legislation.

The other conclusions regarding the definitions of public policy found by the experts, are:

a. Public policy is the determination of government's actions;

b. Public policy is not only stated but implemented;

c. Good public policy to do something or not to do something has, and is based on certain intention and purpose;

d. Public policy must always be addressed to the interests of society.

Hence, the definitions of public policy above confirm that the government is legally able to do something amidst its society; moreover, the choice of the government to do something or not to do something is embodied in the form of allocation of values that grow and thrive in a society where the authority in a political system involved in the daily problems that become their responsibility or their role.

Based on some definitions above, the meaning of public policy can be formulated as:

a. Everything that is done and not done by the government;

b. Public policy is a policy that regulates the coexistence or public life, not the life of an individual or a certain group.

c. Public policy sets all items existing in the domain of public administrator institutions;

d. Public policy is a policy which amount of the benefit should always be addressed to the interests of society. 


\subsection{Factors Influencing The Public Policy}

According to O 'Jones and Thomas [23], in public policy, there are several factors that influence the success of a public policy, namely:

a. Structure; how the relationship between policy actors with those involved/affected by the policy;

b. Responsiveness; how the response of the policy actors against those involved /affected by the policy; how values/traditions that exist in response to things like this.

c. Leadership; how much power and determination of a leader has [24].

Policies made by government is a procedure for absorbing and channeling aspirations, as well as an agreement of the the holders of the sovereignty towards the things and ways that need to be done to ensure the welfare of human beings as a citizen. Thus, the policy is a form of government's responsibility as a component of the government's implementation to the public.

\subsection{The Concept of Public Service}

Hood in [25] argues that customer service can be defined as a management system, which is organized to provide connection of continuous servant between the time of ordering and the time when the goods or services are received and used, that aim to satisfy the customers in the long term. Besides, according to Yun, Yong, and Loh in [26], customer service is the first link in the chain of activities of the upcoming quality management total system.

According to Hardjosoekarto in [27], service and support to customers can be defined as a form of service that provides satisfaction for its customers that is always remembered by its customers;it keeps a positive image in the eyes of the customers; a service at an affordable cost that in turn, the customers may cooperate in excellent service implementation.

Public services can be defined as the provision of services (serving) for the needs of a person or people who have an interest in a particular organization, in accordance with the basic rules and procedures that have been established. As already noted, the government is essentially the servant to the community. They are not meant to serve themselves, but to serve the community and to create a condition that enables every member of the society to develop the ability and creativity to achieve the common goals [28]. Hence, the public bureaucracy is obliged and responsible to provide good and professional service. Public services by the public bureaucracy earlier is an implementation of the state apparatus functioning as a public servant besides being a servant of the state. Public services by public bureaucracy are meant for the welfare of the citizens of a welfare state. Public services by the National Institute of Public Administration are defined as any form of service activities commonly undertaken by the Central Government Agencies and the Regional Government Agencies, and in the State-Owned Enterprises/Region-Owned Enterprises in the form of goods and or services, both within the frameworks of the effort to fulfill the needs of society as well as the implementation of the provision of legislation.

Public services can thus be defined as the provision of services (serving) for the person or people who have an interest in the organization in accordance with the basic rules and procedures that have been established. According to Widodo in [17], the current state of society has been in a very dynamic development; the level of people's lives getting improved is an indication of empowerment experienced by the society. This means that people are increasingly aware of the rights and obligations as a citizen living on the social, state and national environment. People are increasingly daring to deliver claims, expectations and aspirations to the government. The public is progressively critical and increasingly daring to monitor whatever done by the government. In the condition of society as described above, the public bureaucracy must be able to provide public services that are more professional, effective, simple, transparent, open, punctual, responsive and 
adaptable, moreover to be able to simultaneously improve the quality of life in the sense of increasing the capacity of individuals and communities to actively determine their own future [17]. The course of human quality development mentioned earlier is empowering human capacity in the sense of creating condition that allows every member of the society to develop their ability and creativity to organize and determine their own future.

A professional public service means that public services are characterized by the presence of accountability and responsibility from the service providers (state apparatuses), with the following characteristics:

a. Effective; emphasizing more on achieving the goals and objectives;

b. Simple; service procedures implemented are easy, fast, precise, straightforward, easy to understand and easy to implement by the people who ask for services;

c. Clarity and certainty (transparent); containing the meaning of the clarity and certainty regarding:

1) Procedures of service;

2) Terms of service, both the technical requirements and administrative requirements;

3) The working unit or the competent and responsible authorities in providing services;

4) Details of fees/tariffs and payment methods;

5) Schedule of the service completion.

d. Transparency; connotes procedures of the requirements, working unit/governmental officials in charge as the service provider, time of completion, timing details/tariffs and other matters relating to the service process that is required to be informed openly in order to be easily identified and understood by the public, whether requested or not;

e. Efficiency; implies:

1) Terms of service are only limited to the matters directly associated to the achievement of the service objectives by keeping aware of the integration between the terms of services and related product services;

2) In the prevention on the repetition of eligibility, in terms of the public service process, the related party requires their compliance of requirements from the working unit/other related governmental agencies.

f. Punctuality; implies that the implementation of the public service can be completed within a specified time; Responsive; leads to rapid response in addressing the problems, needs and aspirations of the community served;

g. Adaptive; quickly adapted to the demands, desires and aspirations of the people served who are progressing.

Moreover, in a society that exists in an increasingly critical condition, public bureaucracy is required to be able to change the position and role (revitalization) in providing the public services; such changes, for example, if the officials only like to give orders and demands, they have to start trying to serve; if the officials used to use a power approach, they have to start helping towards flexible, collaborative and dialogic course; from applying sloganic ways towards realistic pragmatic ways of working [17]. By the revitalization of the public bureaucracy (especially the local government apparatus), the improved and more professional public services and in carrying out the tasks and authority given to them can be achieved. Theoretically, at least, there are three major functions that should be executed by the government regardless of the positions, including the public service function, the development function and the protection function. The next important thing is the extent to which government can manage these functions in order to produce economical, effective, efficient and accountable goods and services for all the people who need them. In addition, the government is required to apply the principle of equity in performing the functions. This means that governmental services should not be provided in a discriminatory manner. Services are provided regardless of 
status, position, class of society, all citizens have the equal rights on such services in accordance with the applicable law. Although the government has the functions as mentioned above, but it does not mean that the government should act as a monopolist in the implementation of the entire functions. Some parts of these functions could be a task field of the implementation that may be delegated to the private sector or through a partnership model between the government and the private sector. The model of cooperation between government and private sector in providing various services to the public is in line with the idea of reinventing government developed by Osborne and Plastrik [29]. However, in its relation with the nature of private goods and genuine public goods, the government is the only party that is obliged to provide genuine public goods, particularly the public goods known as rules (public policy). Genuine public goods in the form of these rules have not and should not be handed over to private sector. Because if this happened, then, the interests of the private sector, that also drafted the rules, would be attached within the rules, so that the rules would be filled by vested interests that became unfair rules. Therefore, the role of government, that will remain attached throughout its existence, functions as genuine public goods provider named rules. The provision of public services by governmental officials to the society is actually an implication of the state apparatus functions as a public servant. Therefore, the position of the state apparatus in public services is very strategic because it will determine how far the government is able to provide the best possible service for the people, which will thus determine the extent to which the state has to perform its role properly in accordance with the purpose of its establishment. From the economic side, similar to the goods, service is an instrument to satisfy the human needs. However, service has its own distinct characteristics different from the goods. One difference that distinguishes service from the goods, as stated by Gasperz [30], is its non-standardized intangible output that cannot be stored in the inventory, but directly consumed during the production.

The characteristics of service, as presented by Gasperz in [30], clearly differentiate service and goods despite the fact that both are instruments to satisfy the human needs. As the intangible products, services have different dimensions from the tangible goods. The ultimate products of services do not possess physical characteristics as possessed by goods. The ultimate products of services depend on the interaction between the services and the costumers.

In the context of public service, it is noted that the public service should put the public affairs at the first place, facilitate the public affairs, shorten the time of the implementation of public affairs and provide satisfaction to the public. Similarly, Moenir in [3] argues that public service is an activity undertaken by a person or a group of people based on the material factors through the system, procedures and specific methods as an attempt to meet the interests of people in accordance with their rights. From the version of the government, the definition of public service is stated on the Decree of the Minister for Administrative Reform No. 81 of 1993, saying that all forms of services are implemented by the governmental agencies in the central governmental environment, in the regional governmental environment, and in the State-Owned Enterprises (BUMN) or RegionalOwned Enterprises (BUMD) environments, in the form of goods or services, either as an effort to meet the needs of society or in the implementation of the provisions of the legislation.

Book of Delivering Quality Services by Zeithaml, et al. in [31], discussed the feedback and expectations of the customers towards the services they received, either in the form of goods or services. In this case, the purposes of public service in general include how to prepare the public services desired or needed by the public, and how to provide them appropriately to the public regarding their choices and the access planned and provided by the government.

Thus, the purposes are described as follows:

a. To determine any kinds of public services provided; 
b. To treat the service users as customers;

c. To try to satisfy the service users in accordance with their expectation;

d. To find the best delivery of good and qualified services;

e. To provide options if the users has no other option; starting to question the people's satisfaction on what is given by the servant, in this case, the public administration or the government itself, and what they want, which means the extent to which the public expects what eventually they will receive.

Therefore, an evaluation is conducted regarding the expectations and the reality, if it is not the same, the government is expected to thoroughly check the situation for the increase of the public services effectiveness.

Furthermore, it is questionable whether in the completion process of the people's will, the provision of appropriate charges, the time counted and quality demanded by the people are met. If they did not met, the government would be expected to check the situation; on the contrary, if they were met, then the next question was about the various information received by the public regarding the circumstances and the rules that made them up.

\subsection{The Concept of Public Information}

Regarding the definition of Public Information, Act No. 14 of 2008 on Public Information Disclosure states briefly that: "Public Information is the information generated, stored, managed, delivered and/or received by a Public Body with regard to the state administrators and state administration and/or the other public body administrators and administration in accordance with this Act as well as other information related to the public interest". Meanwhile, according to Regulation of the Commission of Information No. 1 of 2010 on the Standard of Public Information Service, public information is the information generated, stored, managed, delivered and/or received by a Public Body with regard to the state administrators and state administration and/or the other public body administrators and administration in accordance with the Act No. 14 of 2008 on Public Information Disclosure as well as other information related to the public interest".

\section{Public Policy in the Realization of the Image of Public Information Service in the Secretariat General of DPR RI}

From the public point of view, information has a significant and strategic role mainly in order to deal with fast-paced society changes and the uncertain situation as well as to reduce anxiety. For a person or an organization, information can be used to improve personal ability, to provide added values, and to help taking a decision in developing the society and the environment. Without the support of information, a person or an organization would not be able to achieve the goals that have been planned.

Information is not just a description given by a person or public body. Information is data, facts, news, or descriptions that have been processed as well as possible in order to have sense and value that is important for a person or organization. Priyatno in [32] state that information is "aggregation or the processing of the data to provide knowledge or intelligence". Priyatno in [32] states that information is meaningful data that convey usable knowledge. The quality of beneficial values of information can also be considered. One of the criteria is the availability of the information itself. When information is needed by the community, it must be provided completely and easy to get, such information can be categorized as available. Moreover, the information must also be easily understood by everyone, relevant to the problems that need to be solved, and useful to those who access it. Information should also be provided on time, especially for the people who really need to solve the problems faced. Sources of information must be reliable, true and accurate. It means that information should be free of errors, clear, and precise; it should have 
straightforward meaning from the supporting data. Lastly, the information should not contain contradictions in the presentation, in other words, it must be consistent.

Based on the interview results with the key informants and the informants of this study, the results of the observation conducted, indicate that procedurally, the public information service held by the Bureau of Public Relations of the Secretariat General of DPR RI in accordance with the Regulation of DPR RI No. 1 of 2010 on Public Information Disclosure in the DPR, reveals that the Regulation is a derivative of the Act No. 14 of 2008. The procedures of public information service have given clear instructions or guidelines for obtaining information related to the activities of the DPR RI. This means that these conditions provide convenience to the public audience that previously encountered difficulties due to the bureaucratic system. It was also wellappreciated by the informants represented by the public figures and journalists of some electronic media. They admited that there are a number of progress, in this case, the procedures to obtain public information that are more easily than the procedures established several years ago. This condition is supported by observations indicating that the procedures of public information service provide convenience for the information applicants. Thus, in general, it can be concluded that the service procedures applied have provided excellent support for the public in obtaining information of the activities of DPR RI, both, regarding its institution and personnel of the members of the DPR RI. Besides the problem of the public information service procedures that get positive evaluation from the stakeholders, the easiness of getting information indicator associated with supporting infrastructure and also the readiness of human resources in providing services, obtains good marks from the key informant or the informants of this study.

Discussion on the quality problem, in this context, does not only refer to the information itself but also with the service. Then, who is actually interested in providing high-quality information to the public? The answer is absolutely the public body. The intended public bodies are all public institutions which administrators obtain funds from a part or all of the state budget (APBN) or the regional budget (APBD), contributions of the community, and/or from abroad. Political parties are also parts of a public body. They are also obliged to provide information related to their authority. The mechanism to obtain information services is that all public bodies must continue to prioritize the quality of the information and the services. Moreover, technically, the quality of service promotes the rapid, punctual, simple, and low-cost principles. To realize these quality services, the provision of Act of Public Information Disclosure, Article 13 suggests that any public body appoints a Manager of Information and Documentation (PPID) with the task of developing a service delivery system that is nationally standardized.

In order to provide public information service, each public body needs to hold eight principles. These eight principles are 1) focusing on customer satisfaction, 2) leadership to unify understanding on the role and direction of the development of information service, 3 ) the processing-approach by giving attention to the linkages with the suppliers of information, 4) the involvement of human resources at all levels of the organization, 5) the use of a system-approach in management, 6) implementation of sustainable improvement, 7), fact-based decision making, 8) mutually beneficial relationships with suppliers of information (Sudarwo, 2006). In addition to having these principles, the Institute of Information Services should also be able to meet the general requirements, namely 1) to identify the quality management system process that is required, to and apply it to the entire organization, 2) to determine the interaction and the sequence of the process, 3) to establish criteria and methods to ensure the operation effectiveness and to control the process, 4) to ensure the availability of resources and information to support the operation and the monitoring process, 5) to carry out the monitoring, assessment, and analysis of the performance of the process, and 6) to implement actions to ensure the achievement of the plans made and the sustainable improvement. These benchmarks of the citizens' satisfaction depend on the information service quality rendered by the public 
bodies. The quality can be seen from the fourteen elements that are relevant, valid, and reliable. The fourteen elements are minimal elements that must exist for the basis measurement of quality and satisfaction of the people, including, first is the easy procedures and simple service flow, second is the compliance between the requirements of service with the type of service, third is the clarity of the service official, incuding his/her name, position, authority and responsibility, fourth is discipline and sincerity of the official in providing service. This sincerity can be seen from the consistency of the working time during the service.

The next element is the clarity of the authority and responsibility of the staff in the administration and completion of the service. Sixth is the ability that includes the expertise and skills of officers in providing services. Speed of service as the seventh element is the target of a predetermined time in order to be able to provide and complete the services. The eighth is to provide a sense of justice to the people who have different classes and status. Ninth is the courtesy and hospitality of the staff in delivering services. Courtesy and hospitality can be monitored by the attitudes and behaviors of mutual respect with fellow customer. The next important thing is associated with the service fairness and certainty. The fairness is the affordability of the service charge that has been set by the unit of service to the people. While certainty in this respect can be the tangible cost and schedule of the service. Certainty of the service charge is the total cost of service between the fees paid and the cost that has been determined. Moreover, what is meant by certainty of the service schedule is the implementation of service time in accordance with the provisions stipulated. Environmental comfort in providing services should also get attention. Conditions of the service infrastructure which are immaculately clean and tidy can provide a sense of comfort to the service users. It is the same with the security of the service. Security of the service is guaranteeing the security level of the environmental unit or service provider and the infrastructure used, so that people feel at ease to obtain the service without worrying the risks resulting from the implementation of the service. In response, the DPR RI issued the Regulation of DPR RI No. 1 of 2010 on Public Information Disclosure in the DPR RI and the regulation is a derivative of Act No. 14 of 2008 on Public Information Disclosure as a legal basis and philosophy for the implementation of public information service activity in the environment of the DPR RI (the Parliament). The Secretariat General of the DPR RI becomes the one that takes full responsibility and acts as the actor of the implementation of public information service. Public information that can be accessed by the public is related to the activities of the DPR RI in carrying out its function as a abody of monitoring, legislation and budgeting. In the context of the implementation of the main tasks and functions, people need and have the rights to know that the implementation of governance can run effectively in expanding the mandate of the people's suffering. According to Widodo [17], the current state of society has been in a very dynamic development, the improved level of people's lives indicates the empowerment experienced by the society. This means that people are increasingly aware of what are their rights and obligations as citizens in social, state and national environment. People are increasingly daring to make demands, desires and aspirations to the government. The public is increasingly critical and increasingly daring to exercise control over what is done by the government. In conditions of society as described above, the public bureaucracy must be able to provide public services that are more professional, effective, simple, transparent, open, punctual, responsive and adaptable. Moreover, the public services should be able to simultaneously improve the quality of life in the sense of increasing the capacity of individuals and communities to actively determine their own future [17]. The direction of the human quality improvement is empowering human capacity in the sense of creating conditions that allow every member of the community develop their abilities and creativity to organize and determine their own future. 
The implementation of the public servicen must comply the principles as stipulated in Act No. 14 of 2008 on Public Information Disclosure that it is in line with simple procedures, in line with the goals and targets of activities involving the human resources and adequate infrastructures, meets the principles of transparency, accountability, efficiency and effectiveness, thereby it builds a positive image of public service bodies. Related to this case, the key informant or informants of the study provide a statement that in general, there have been improvements in the public information services but they assume that the service improvements have not been entirely satisfactory for the public. However, there is existing goodwill of the implementers in order to improve services to the public so that people can be more easily and quickly to access the information needed. In the context of public service, it is noted that the public service puts public affairs at the first place, facilitates the public affairs, shortens the implementation schedule and gives satisfaction to the public. Similarly, Moenir in [3] argues that public service is an activity undertaken by a person or a group of persons based on the material factors through the system, procedures and specific methods in an attempt to meet the interests of people in accordance with their rights.

According to Hardjosoekarto in [27] service and support to customers can be defined as a form of service that provides satisfaction for its customers that is always remembered by its customers, provides a positive image in the eyes of its customers, given at an affordable cost, so that, in turn, customers can cooperate in the implementation of excellent service. Public services can be defined as the provision of services (serving) for the person or people who have an interest in a particular organization and in accordance with the ground rules and procedures established. As already noted, the government is essentially a service to the community. They do not exist to serve themselves, but to serve the people and create conditions that enable every member of society develop their abilities and creativity to achieve the common goals (Rashid, 1998:120). Hence, the public bureaucracy is obliged and responsible to provide good and professional service. Public services by public bureaucracy is one embodiment of the state apparatus functions as a public servant besides having a role as a state servant. Public services by public bureaucracy meant for the welfare of citizens of a welfare state. More detailed conditions of public information service held by the Bureau of Public Relations of the Secretariat General of the DPR RI can be described as follows:

a. Transparency in public information services has significant impacts for the citizens as service users. Society obtains a good impact by implementation of the the public services in the Bureau of Public Relations of the Secretariat General of the DPR RI when people get the factual information. Improved information services is characterized by the performance improvement done in various ways such as improved efficiency. Information services have increasingly become an important profession. Information services include all forms of services, either in the form of goods or services. Information services are the responsibility undertaken by the Bureau of Public Relations of the Secretariat General of the DPR RI to maintain or improve the quality of people's lives. By the implementation of the principle of transparency, the public information service is able to provide the public rights for the public information. Based on the study results, it is indicated that the Bureau of Public Relations of the Secretariat General of the DPR RI has been able to apply the principle of transparency of public information. This means that the information released by the Bureau of Public Relations of the Secretariat General of the DPR RI has met the rights for the public information.

b. Efficiency in information services impacts the citizens as the users of services. Society gets a good impact by the presence of the public service in the Bureau of Public Relations of the Secretariat General of the DPR RI, such as saving time. Improved information services is characterized by performance improvement done in various ways such as improved efficiency. Information services have increasingly 
become an important profession. Information services are all forms of services, either in the form of goods or services. Information services are the responsibility undertaken by the Bureau of Public Relations of the Secretariat General of the DPR RI to maintain or improve the quality of people's lives. The low quality and effective information services have spawned a multidimensional effect.

c. Effective information services are determined from the policy of information service programs run by the Bureau of Public Relations of the Secretariat General of the DPR RI. Information services aim to improve the quality of people's lives. Bureau of Public Relations of the Secretariat General of the DPR RI in performing their duties and functions is evaluated with benchmarks and clear standards. In the context of being effective to improve the sensitivity, the Bureau of Public Relations of the Secretariat General of the DPR RI sets the goals or targets of any policies implemented. Thus, there is an increase in the efficiency and effectiveness of the implementation of the public information services held by the Bureau of Public Relations of the Secretariat General of the DPR RI. The principles of efficiency and effectiveness can support the society in conducting control over the work of the government in accordance with the ability to criticize the public services including the public information of the Parliament.

d. Accountability in the public services performance in the Bureau of Public Relations of the Secretariat General of the DPR RI makes progress along the existence of the code of conduct and trainings. The trainings organized by the Bureau of Public Relations of the Secretariat General of the DPR RI create visible progress that can be noticed from the service unit in the Bureau of Public Relations of the Secretariat General of the DPR RI for the public.

e. Simplicity in providing public information services is particularly capable of impacting the citizens as the service users. Simplicity in this case is all kinds of public information services that are simply presented both in terms of contents and procedures. Thus, people who use public information services can understand the content of the information properly. The simplicity in the context of public service is defined by the Bureau of Public Relations of the Secretariat General of the DPR RI as to provide information in an easy procedure as well as to obtain such information directly and the service users do not have to pass through a long bureaucratic flow. Based on the interviews and observations conducted, it can be concluded that the Bureau of Public Relations of the Secretariat General of the DPR RI has been able to provide public information simply in terms of content and procedures for obtaining the relevant information. This means that at this point, the public information services conducted by the Bureau of Public Relations of the Secretariat General of the House of Representatives have increased significantly indicated from the simplicity principle of public service.

f. Transparency in the process of public services implies that all information provided to the public is the correct information in accordance with the facts. This means that public information is cannot be separated from the actual conditions in accordance with the content presented to the public. In the context of the transparency of the Bureau of Public Relations of the DPR RI, it is completely aware of the its functions and responsibilities to provide information related to the activities of the Parliament that turns to be the public rights to know. Based on interviews and observations conducted, it can be concluded that at some point, the Bureau of Public Relations of the Secretariat General of the DPR RI has been able to provide the widest possible access for the public to obtain factual public information. However, for some cases, the Bureau of Public Relations of the Secretariat General of the DPR RI is still not able to open wider access, for example, regarding thetransparency of the budgeting used to finance various activities. Related to the information of the overseas visit conducted by the members of the Parliament, the Bureau of the Public Relations of 
the Secretariat General of the DPR RI is still not willing to provide such information openly, whether information of their activity, or especially information associated with the use of the required budget details.

g. The punctuality is closely linked to the principle of actual, factual and accurate information. The principle of punctuality in the context of information becomes very significant that the feedback to this information can also be carried out in a punctual time as well. Regarding this principle of punctuality, the Bureau of Public Relations of the Parliament has not been able to apply this principle. This condition has a major impact on service users, especially journalists in the process of presenting the news that must be in accordance with the principle of actual, factual and accurate information mentined previously. This condition is an obstacle that must be tackled by the public information services within the DPR RI. Under certain conditions, the journalists have to find news from the members of Parliament to address specific issues since the Bureau of Public Relations of the Secretariat General of the DPR does not provide the information quickly.

h. Being responsive in the context of public service implies that public information service providers are required to give an adequate response to the complaints of the citizens. Through a quick response, the improvement process on the public services can be done in a better way. When the responses provided are well received by the service users, then they may get satisfaction in a relative context. In the context of responsiveness, the Bureau of Public Relations of the Secretariat General of the DPR RI has not been able to give positive repsonses for any complaints filed by the members of the society. Based on interviews with key informants and field observations, it can be noticed that the majority of public complaints is related to comprehensive information transparency, especially related to budgeting and the overseas visit of the members of Parliament, that is still not available. Regarding the complaints, the Bureau of Public Relations of the Secretariat General of the DPR RI has not been able to give a positive response, so that people do not feel satisfied on such services.

i. Being adaptive in information services impacts the citizens as the service users. A good adaptation of the state officials associated with the development of society and the development of technology needs to be performed. It cannot be separated from the rapid flow of democratization as what people understand, hence, all people need to know all kinds of information that is financed by taxes. Democratization movement developed in the society demands the fulfillment of all the information constructed. At this point, the process of adaptation of the Bureau of Public Relations of the Secretariat General of the DPR RI becomes very vital. Based on interviews with key informants and the results of field observations, it is shown that the adaptability of public information service is already running in the right direction. The Bureau of Public Relations of the Secretariat General of the DPR RI is capable in adopting the information and communication technologies, so that the provision of public information is well organized and accessible for the public.

\section{Conclusion}

Based on studies that have been conducted on the image of the public service of the Secretariat General of the House of People's Representatives of the Republic of Indonesia (DPR RI), there are several conclusions obtained, including: (1) Transparency in public information services provides a significant impact to the citizens as the service users. Based on the study results, it is indicated that the Bureau of Public Relations of the General Secretariat of the DPR RI has been able to apply the principles of transparency of public information. This means that the information released by the Bureau of Public Relations of the Secretariat General of the DPR RI has fulfilled the rights of public 
information; (2) Effectiveness in the information service is determined by information service policy programs run by the Bureau of Public Relations of the Secretariat General of the DPR RI. Hence, there is an increase in the efficiency and effectiveness of the implementation of public information services held by the Bureau of Public Relations of the Secretariat General of the DPR RI. The principles of efficiency and effectiveness can support the citizens in conducting control over the government with the ability to criticize the public services including public information of the Parliament; (3) Accountability in the public service in the Bureau of Public Relations of the Secretariat General of the DPR $\mathrm{RI}$ indicates that the performance of public services makes some progress with the code of conduct and trainings. The trainings organized by the Bureau of Public Relations of the Secretariat General of the DPR RI create the visible progress of the service unit in the Bureau of Public Relations of the Secretariat General of the DPR RI provided for the public; (4) Simplicity in providing public information services in particular is able to impact the community as the service users. Based on the interviews and observations, it can be concluded that the Bureau of Public Relations of the Secretariat General of the DPR RI has been able to provide public information simply, in terms of both content and procedures in obtaining the relevant information; (4) The transparency in the public service provided to the public means that the information given to the public is in accordance with the facts. Based on interviews and observations conducted, it can be concluded that at some point the Bureau of Public Relations of the Secretariat General of the DPR RI has been able to provide the widest possible access for the public to obtain factual public information; (5) The punctuality is closely linked to the principle of actual, factual and accurate information. The principle of punctuality in the context of information becomes very significant that the feedback to this information can also be carried out in a punctual time as well. Regarding this principle of punctuality, the Bureau of Public Relations of the Parliament has not been able to apply this principle; (6) Being responsive in the context of public service implies that public information service providers are required to give an adequate response to the complaints of the citizens. Based on interviews with key informants and field observations conducted, it can be noticed that the majority of public complaints is related to comprehensive information transparency, especially related to budgeting and the overseas visit of the members of Parliament, that is still not available.

\section{Acknowledgement}

This research is supported by Universitas Nasional research grant.

\section{References}

[1] A. Farazmand, "Role of government in an era of total quality management (TQM) and globalization: Challenges and opportunities", Public Organization Review, vol. 5, no. 3, (2005), 201-217.

[2] D. Epple and R. E. Romano, "Ends against the middle: Determining public service provision when there are private alternatives", Journal of Public Economics, vol. 62, no. 3, (1996), pp. 297-325.

[3] H. A. S. Moenir, "Manajemen Pelayanan Umum di Indonesia", Jakarta: Bumi Aksara, (1998).

[4] J. P. Charkham, "Keeping good company: A study of corporate governance in five countries", Oxford University Press, (1995).

[5] J. Graham, B. Amos and T. Plumptre, "Principles for good governance in the 21st century", Policy brief, vol. 15 , no. 6 , (2003).

[6] M. Lockwood, "Good governance for terrestrial protected areas: A framework, principles and performance outcomes", Journal of environmental management, vol. 91, no. 3, (2010), pp. 754-766.

[7] O. E. Hughes, "Public management and administration", Palgrave Macmillan, (2012).

[8] Y. Kresnayana, "Enterprise Resource Planning di Perusahaan dalam Menghadapi Era AFTA", Seminar Talk at Universitas Kristen Petra, (2003).

[9] V. A. Lambert and C. E. Lambert, "Qualitative descriptive research: an acceptable design", Pacific Rim International Journal of Nursing Research, vol. 16, no. 4, (2012), pp. 255-256.

[10] R. Thomas Dye, "Understanding Public Polic", Engelewood Chief, New Jersey Prentince-Hall Inc, (1987), p. 3. 
[11] R. Nugroho, "Public Policy", Jakarta : Elex Media Komputindo, (2009).

[12] P. Bridgman and G. Davis, "The Australian Policy Handbook", Crows Nest: Allen and Unwin, (2004).

[13] B. W. Hogwood and L. A. Gunn. "Policy Analysis for The Real World", Oxford: Oxford University Press, (1990).

[14] N. W. Dunn, “Analisis Kebijakan Publik (Translator: Muhadjir Darwis)”, Yogyakarta: Hanindita, (2003).

[15] H. N. S. Tangkilisan, "Kebijakan Publik yang Membumi: Konsep, Strategi, dan Kasus", Yogyakarta: Lukman Offset dan Yayasan Pembaruan Administrasi Publik Indonesia, (2003).

[16] G. C. Edward, "Public Policy Implementing", London: Jai Press Inc, (1984).

[17] J. Widodo, "Membangun Birokrasi Berbasis Kinerja", Malang: Bayu Media, (2006).

[18] S. Wahab, "Analisis Kebijakan: Dari formulasi ke Implementasi Kebijaksanaan Negara”, Jakarta: Bumi aksara, (2005).

[19] R. T. Nakamura and F. Swallwood, “The Polities of Policy Implementation”, New York: St. Martin Press, (1980).

[20] M. Budiardjo, “Dasar-dasar ilmu politik”, Gramedia pustaka utama, (2003).

[21] J. Widodo, "Good governance: telaah dari dimensi akuntabilitas dan kontrol birokrasi pada era desentralisasi dan otonomi daerah", Insan Cendekia, (2001).

[22] M. I. Islamy, "Prinsip-prinsip Kebijakan Negara", Jakarta: Bumi Aksara, (2001).

[23] C. O. Jones and R. D. Thomas, "Public policy making in a federal system", Sage Publications, Inc, vol. $3,(1976)$

[24] L. Agustino, "Dasar-Dasar Kebijakan Publik", Bandung: CV. Alfabeta, (2006).

[25] C. Hood, “A public management for all seasons?", Public administration, vol. 69, no. 1, (1991), pp. 319.

[26] Z. Y. Chang, W. Y. Yeong and L. Loh, "Critical success factors for Inflight Catering services: Singapore Airport Terminal Services' practices as management benchmarks", The TQM Magazine, vol. 9, no. 4, (1997), pp. 255-259.

[27] S. Hardjosoekarto, "Construction of social development index as a theoretical research practice in action research by using soft systems methodology", Systemic Practice and Action Research, vol. 25, no. 6, (2012), pp. 493-509.

[28] Z. Abdul Rashid, M. Sambasivan and J. Johari, "The influence of corporate culture and organisational commitment on performance", Journal of management development, vol. 22, no. 8, (2003), pp. 708-728.

[29] D. Osborne and P. Plastrik, "Memangkas Birokrasi, Lima Strategi Menuju Pemerintahan Wirausaha", (Translation: Abdul Rosyid dan Ramelan), Jakarta: PPM, (2000).

[30] V. Gaspersz, "Experimental Setup Method", (1994).

[31] V. A. Zeithaml, A. Parasuraman and L. L. Berry, "Delivering quality service: Balancing customer perceptions and expectations", Simon and Schuster, (1990).

[32] D. Priyatno, "Teknik Mudah dan Cepat Melakukan Analisis Data Penelitian SPSS dan Tanya Jawab", Yogyakarta: Gava Media, (2001).

[33] G. Kartasasmita, "Administrasi Pembangunan Perkembangan Pemikiran dan Prakteknya di Indonesia", Jakarta: PT Pustaka LP3ES, (1997).

[34] H. Koontz, C. O'donnell and J. Halff, "Management: A systems and contingency analysis of managerial functions", McGraw-Hill Kogakusha, Inc. Tokyo, (1976).

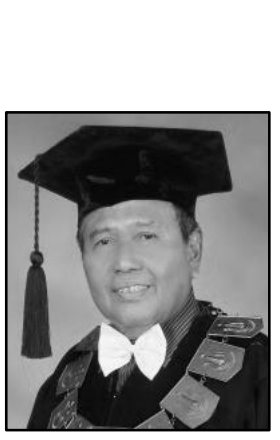

\section{Author}

Eko Sugiyanto is an associate professor in Administrative science at Faculty of Social and Political Science, National University, Indonesia. He received Bachelor of Science from National University in 1982, Master of Social Science from Gadjah Mada University Yogyakarta in 1992 and $\mathrm{PhD}$ from Padjajaran University in 2012. He has been a faculty member at National University, Indonesia since 1982 . He is presently a deputy of rector in human resource, administration and finance of National University, Indonesia. His research focusses in the field of administration science, political science and public service. 